\title{
Letermovir profilaxis allogén vérképző-őssejt transzplantációban: egy hazai centrum gyakorlati tapasztalatai
}

\author{
Sinkó János ${ }^{1, @}$, Körösmezey Gábor ${ }^{2}$, Paksi Melinda ${ }^{1}$, Gopcsa László ${ }^{1}$, Reményi Péter ${ }^{1}$ \\ ${ }^{1}$ Dél-pesti Centrumkórház - Országos Hematológiai és Infektológiai Intézet, \\ Hematológiai és Őssejt-transzplantációs Osztály, Budapest \\ ${ }^{2}$ Magyar Honvédség Egészségügyi Központ, I. Belgyógyászati Osztály, Budapest
}

\begin{abstract}
Bevezetés: A humán cytomegalovírus infekció direkt és indirekt szövődményei napjainkban is veszélyeztetik az allogén őssejt-transzplantációval kezelt betegeket. A széles körben alkalmazott preemptív stratégia mellett előnyös lehet a kórokozó reaktivációjának megelőzése profilaktikusan adagolt vírusellenes vegyülettel. A letermovir innovatív hatásmechanizmusú, szűk spektrumú antivirális szer, mely allogén őssejt-transzplantáltak körében végzett, placebo kontrollált klinikai vizsgálatban csökkentette a cytomegalovírus infekciók gyakoriságát és javította a túlélést. A szerzők 23, allogén őssejt-transzplantált beteg retrospektív módon gyűjtött adatait ismertetik, akik a beavatkozás kapcsán letermovir profilaxisban részesültek. A betegek több mint fele akut leukémiában szenvedett, harmaduk aktív betegséggel került transzplantációra, kétharmaduk donora haploidentikus egyezést mutatott. A letermovir adagolása során 2 , azt követően további 3 személyben lépett fel cytomegalovírus infekció. Szervi érintettséggel járó cytomegalovírus betegség egyetlen esetben sem alakult ki. A megfigyelési időszak során 2 fő hunyt el, cytomegalovírustól független okok miatt. Az alkalmazhatóságot korlátozó mellékhatást nem észleltek. A letermovir a mindennapi klinikai gyakorlatban is hatékonynak és biztonságosnak bizonyult az őssejt-transzplantáltak cytomegalovírus fertőzésének megelőzésére.
\end{abstract}

Kulcsszavak: humán cytomegalovírus, allogén vérképző-őssejt átültetés, letermovir, antivirális profilaxis

\section{Letermovir prophylaxis in allogeneic hematopoietic stem cell transplantation: real-life experience in a Hungarian center}

Introduction: Direct and indirect effects of cytomegalovirus infection remain an ongoing threat to patients treated with allogeneic stem cell transplantation. In addition to the widely used preemptive approach, prevention of viral replication with a prophylactically administered antiviral drug seems to be feasible. Letermovir, a narrow-spectrum antiviral compound with an innovative mechanism of action, has been shown to decrease the incidence of cytomegalovirus infection and to improve survival in a placebo-controlled clinical trial recruiting allogeneic stem cell transplant patients. Authors present retrospectively collected data from 23 patients receiving letermovir prophylaxis as a part of their allogeneic stem cell transplantation procedure. More than half of prophylaxed individuals had acute leukemia, a third of them underwent transplantation with an active disease and two third of the cohort had a haploidentical donor. During prophylaxis 2, subsequently further 3 patients developed a cytomegalovirus infection. No organ-specific disease could be detected. Through the observational period 2 patients have died due to causes unrelated to cytomegalovirus. No side effect interfering with drug use could be revealed. In this real-life case series letermovir has been shown to be effective and safe for the prevention of cytomegalovirus infection in allogeneic stem cell transplant patients.

Keywords: human cytomegalovirus, allogeneic hematopoietic stem cell transplantation, letermovir, antiviral prophylaxis

(Beérkezett: 2021. november 2.; elfogadva: 2021. november 5.)

\footnotetext{
@ Levelezési cím: Sinkó János, Hematológiai és Őssejt-transzplantációs Osztály, Dél-pesti Centrumkórház - Országos Hematológiai és Infektológiai Intézet, 1097 Budapest, Albert Flórián u. 5-7.; Tel.: +36-1-455-8100; E-mail: janos.sinko@dpckorhaz.hu
} 


\section{Rövidítések}

AML - acut myeloid leukaemia; ALL - acut lymphoid leukaemia; CR1-3 - első-harmadik komplett remisszió; D - donor; hCMV - humán cytomegalovírus; HHV-6 - humán herpesvírus-6; HLH - haemophagocytás lymphohistiocytosis; HSV - herpes simplex vírus; MDS - myelodysplasiás szindróma; MUD - egyező idegendonor; PGCy - post-graft ciklofoszfamid; PR - parciális remisszió; $\mathrm{R}$ - recipiens; TDM - therapeutic drug monitoring, terápiás gyógyszerszint monitorozás; VZV - varicella zoster vírus; GvHD - graft-versus-host betegség

\section{Bevezetés}

A humán cytomegalovírus (hCMV) a herpesvírusok közé tartozó DNS vírus, mely a Föld felnőtt lakosságának többségében élethosszig tartó, látens, perzisztáló infekciót okoz $[1,2]$. Míg az ép immunrendszerű személyek hCMV infekciója ritkán jár veszélyes szövődményekkel, a T-lymphocitákhoz kötődő immunválasz károsodása kapcsán a vírus reaktiválódik, ennek nyomán pedig szervi/szöveti károsodás, akár halálos kimenetelhez vezető hCMV betegség léphet fel. A leginkább veszélyeztetett betegcsoportok közé tartoznak az allogén vérképző őssejttranszplantációval vagy bizonyos immunterápiákkal kezelt hematológiai betegek, a szervtranszplantáltak, valamint az előrehaladott HIV fertőzésben szenvedő személyek. A már kialakult hCMV betegség antivirális kezelésére gyakran megkésve kerül sor, így annak eredményei kedvezőtlenek. Kockázati tényezőkkel terhelt betegcsoportokban ezért előnyösebb a preemtív terápiás stratégia, illetve az antivirális profilaxis alkalmazása. Előbbi esetében vírusspecifikus marker (rendszerint hCMV DNS kópiaszám) monitorozásával nyílik lehetőség a korai reaktiváció felismerésére és vírusellenes kezelés elindítására. Profilaxisról akkor beszélhetünk, ha a kockázati időszak folyamán, még a vírus aktiválódását megelőzően, valamely hatékony antivirális vegyület folyamatos adagolása révén előzzük meg a fertőzés kialakulását [3, 4]. Mindkét eljárás során problémát okoz, hogy a hagyományos, hCMV-re ható szerek alkalmazhatóságukat korlátozó, jelentős mellékhatásokkal terhelik a kezelt betegeket.

A letermovir a hCMV-re specifikusan ható antivirális vegyület, mely a vírus DNS termináz komplexét (pUL51, pUL56, pUL89) célozva a nukleinsav processzálását és csomagolását gátolja meg. Egyéb herpesvírusokra nem hat. Gyógyszer-interakciói a CYP3A4 enzim mérsékelt gátlásán és transzporterek révén érvényesülnek. Klinikai szempontból kiemelendő, hogy ciklosporin A-val együtt adva a letermovir napi adagját felezni kell, illetve a voriconazol szérumszintjét csökkentő kölcsönhatása miatt a gombaellenes szer farmakokinetikáját terápiás gyógyszerszint monitorozás (TDM) révén ellenőrizni kell [5].

Marty és mtsai hCMV-szeropozitív, allogén őssejttranszplantáltak körében végzett randomizált, placebo kontrollált klinikai vizsgálatukban 14 héten át adagolt intravénás vagy orális letermovir profilaxis hatékonyságát vizsgálták. Az eredményeket a 24. héten értékelték. Esze- rint a klinikailag szignifikáns hCMV infekció aránya 60,6\%-ról 37,5\%-ra csökkent a kontroll karhoz képest $(p<0,001)$. Egyidejűleg csökkent az összhalálozás is $(15,9 \%$ vs. $10,2 \%, p<0,03)$. A túlélésben tapasztalt különbség, nem szignifikáns mértékben ugyan, de a 48 . héten is kimutatható volt. A mellékhatások aránya és súlyossága nem különbözött a két vizsgálati karban [6].

Hazánkban 2019 novemberétől nyílt lehetőség nagykockázatú allogén őssejt-transzplantált betegek számára - hatósági engedélyek birtokában - letermovir profilaxis alkalmazására. A következőkben a valós élet klinikai gyakorlatában a letermovirral szerzett tapasztalatokról számolunk be.

\section{Betegek és módszerek}

A retrospektív elemzést 2019. november és 2021. január között a Dél-pesti Centrumkórház - Országos Hematológiai és Infektológiai Intézet Hematológiai és Őssejttranszplantációs Osztályán allogén őssejt-transzplantációval kezelt és letermovir profilaxisban részesült 23 személy adatainak felhasználásával végeztük. Az érintettek adataik tudományos célú, anonim felhasználásába a beavatkozás előtt írásban beleegyeztek. Az eredményeket a Medworks medikai rendszerből és az osztályos betegdokumentációból gyüjtöttük. Az elemzés leíró statisztikai módszerekkel történt. Letermovir profilaxist kaptak mindazok a betegek, akik allogén őssejt-transzplantációban részesültek és az azt megelőző vizsgálatok során hCMV IgG szeropozitívnak bizonyultak, illetve akik számára a szer alkalmazását a hatóságok engedélyezték. A profilaxis folyamán és azt követően, az irányelveknek megfelelően, legalább heti rendszerességgel végeztünk mennyiségi PCR (qPCR) vizsgálatot a plazmában található hCMV DNS mennyiségének meghatározására. Ahol az klinikailag indokolt volt, illetve mérhető kópiaszám esetén, a mintavételek gyakrabban történtek. Járóbetegek ellenőrzése során ugyanakkor a mérések gyakoriságát a kontrollvizsgálatok időzítésétől tettük függővé. A PCR-vizsgálatok COBAS TaqMan rendszer alkalmazásával történtek. A módszer hCMV DNS detektálási küszöbértéke 137 IU/ml volt. Klinikailag szignifikáns hCMV reaktivációt akkor állapítottunk meg, ha a DNS mennyisége $1000 \mathrm{IU} / \mathrm{ml}$ fölé emelkedett, és/vagy a profilaxis megszakítása mellett más vírusellenes terápia (foscarnet, ganciclovir) bevezetése vált szükségessé. Mivel a letermovir szük spektrumú vírusellenes szer, haploidentikus transzplantációval, illetve posztgraft ciklofoszfamiddal kezeltek számára a megtapadásig $90 \mathrm{mg} / \mathrm{m}^{2} /$ nap foscarnetet, illetve valamennyi beteg részére standard dózisú aciclovir profilaxist adagoltunk. A betegek demográfiai adatai és transzplantációs jellemzői mellett értékeltük a klinikailag szignifikáns hCMV infekció előfordulását a profilaxis folyamán és azt követően, a társuló egyéb vírusinfekciókat, a szervi vírusbetegség kialakulását és kimenetelét. 


\section{Eredmények}

A vizsgálati időszak folyamán összesen 57 beteg esetében merült fel letermovir profilaxis indikációja, közülük 3 személy esetében egyéb szövődmények miatt nem került sor a szer bevezetésére. A fennmaradó 54 betegből 32 esetben az adatok hiánya, illetve a követési idő nem tette lehetővé a retrospektív elemzést. Így végül 23 személy kórlefolyásának értékelésére került sor. A medián követési idő 174 (34-423) nap volt. A betegek demográfiai adatait és transzplantációs jellemzőit az 1. táblázatban tüntettük fel.
A letermovir adagolására a medián +22. (13-28.) poszttranszplantációs napon került sor. A napi dózis minden esetben $480 \mathrm{mg}$ volt. A profilaxis hossza medián 84 (64107) nap volt.

Klinikailag szignifikáns hCMV infekció a letermovir adagolása alatt 2 betegben, az adagolás felfüggesztése után, a követési idő folyamán, további 3 személyben volt megállapítható. Szervi érintettséggel járó hCMV betegség egy esetben sem lépett fel. A letermovir felfüggesztésével párhuzamosan elkezdett egyéb hCMV ellenes terápia minden esetben hatásos volt. Az áttöréses infekciók kapcsán a vírus genetikai rezisztenciájának elemzésére

1. táblázat. A betegek demográfiai és transzplantációs jellemzői

\begin{tabular}{|c|c|c|c|}
\hline & Mutató & Érték & $\sim \%$ \\
\hline \multirow[t]{4}{*}{ DEMOGRÁFIA } & Betegek száma & 23 & \\
\hline & Medián életkor év & $41(19-60)$ & \\
\hline & Férfi & 12 & 52 \\
\hline & Nő & 11 & 48 \\
\hline \multirow[t]{4}{*}{ DIAGNÓZIS } & AML & 8 & 34 \\
\hline & ALL & 5 & 22 \\
\hline & MDS & 5 & 22 \\
\hline & EGYÉB & 5 & 22 \\
\hline \multirow[t]{4}{*}{ STÁTUSZ } & CR1 & 12 & 52 \\
\hline & $\mathrm{CR} 2$ & 1 & 4 \\
\hline & CR3 & 2 & 9 \\
\hline & Aktív betegség & 8 & 34 \\
\hline \multirow[t]{3}{*}{ DONOR } & Haploidentikus & 15 & 65 \\
\hline & MSD & 5 & 22 \\
\hline & MUD & 3 & 13 \\
\hline \multirow[t]{3}{*}{ GvHD prevenció } & PGCy & 11 & 48 \\
\hline & TCRalfabeta sejtdepléció & 4 & 17 \\
\hline & Egyéb & 8 & 34 \\
\hline \multirow[t]{2}{*}{ hCMV szerostátusz } & $\mathrm{D}+/ \mathrm{R}+$ & 18 & 78 \\
\hline & $\mathrm{D}-/ \mathrm{R}+$ & 5 & 22 \\
\hline
\end{tabular}

AML - acut myeloid leukaemia; ALL - acut lymphoid leukaemia; MDS - myelodysplasiás szindróma; CR1-3 - első-harmadik komplett remisszió; MSD - egyező testvérdonor; MUD - egyező idegendonor; PGCy - poszt-graft ciklofoszfamid; D - donor; R - recipiens

2. táblázat. Értékelt betegek kórlefolyásának kimenetele a megfigyelési időszak végén

\begin{tabular}{llcc}
\hline & \multicolumn{1}{c}{ Mutató } & Érték & $\sim \%$ \\
\hline \multirow{2}{*}{ KIMENETEL } & Él CR & 18 & 78 \\
& Él PR & 1 & 4 \\
& Él relapszusban van & 2 & 9 \\
& Elhunyt & 2 & 9 \\
\hline \multirow{2}{*}{ HALÁLOKOK } & HLH & 1 & \\
& Disszeminált adenovírus infekció & 1 & \\
\hline
\end{tabular}

CR - komplett remisszió; PR - parciális remisszió; HLH - haemophagocytás lymphohistiocytosis 
nem volt módunk. Nyolc betegben ugyanakkor humán herpesvírus-6 (HHV-6), 1 betegben adenovírus infekciót igazoltunk. A követési időszak végén megállapított kimenetelt a 2. táblázatban foglaltuk össze. A letermovir alkalmazásával összefüggésben az adagolást befolyásoló mellékhatást nem észleltünk.

\section{Megbeszélés, következtetések}

Jelen esetsorozat egy hazai őssejt-transzplantációs központ első, valós életből származó - vagyis betegágy mellett szerzett - tapasztalatait adja közre. Tekintettel arra, hogy a letermovir adására elsősorban gyakorlati klinikai felhasználás, nem pedig tudományos kutatás céljából került sor, a betegek több mint felének adatai elemzésére nem adtak lehetőséget. Annyi azonban az összes kezelt személy vonatkozásában megállapítható, hogy az adagolás során a biztonságosságra vonatkozó kedvezőtlen tapasztalat nem merült fel. A szer forgalomba hozatali engedélyét megalapozó klinikai vizsgálattal szemben centrumunkban magasabb hCMV DNS kópiaszám esetén mérlegeltük a profilaxis megszakítását és más vegyület preemptív alkalmazását. Marty és mtsai magas kockázatú betegek esetében 150, a vizsgálati személyek fennmaradó hányadában, illetve a későbbi monitorozás folyamán 300 kópia/ml küszöbértéket alkalmaztak [6]. Az általunk profilaxisban részesített betegek vonatkozásában egységesen $1000 \mathrm{IU} / \mathrm{ml}$ értéket vettünk figyelembe, mely az alkalmazott PCR-teszt esetén 1099 kópia/ml-nek felelt meg. A határérték megállapításánál felhasználtuk a korábbi időszak klinikai tapasztalatait és azt a tényt, hogy a letermovir hatásmechanizmusa nem a vírus DNS szintézisét gátolja, hanem egy annál későbbi szakaszt érint, így nukleinsav annak ellenére kimutatható marad, hogy fertőzőképes vírus már nincs jelen a plazmában [7].

Különbséget találtunk a nemzetközi vizsgálatba bevont betegek és az általunk kezelt személyek között abban a tekintetben is, hogy milyen arányban voltak hCMV infekció vonatkozásában magas kockázatúak (haploidentikus vagy nem egyező transzplantáció, szeronegatív donor). Előbbiben a betegek 31\%-a, míg centrumunkban $74 \%$-a volt ebbe a csoportba sorolható.

Az eltérő határértékek és az alacsony betegszám miatt nincs mód arra, hogy az észlelt hatékonyságot más, valós életből származó, publikált eredményekkel összehasonlítsuk $[8,9]$. Annyi azonban mindenképp megállapítható, hogy a letermovir profilaxist megelőző időszak során, 2018-ból gyüjtött retrospektív adatok minimálisan 41\%-os hCMV reaktivációs arányt bizonyítanak [a szerzők saját, nem publikált megfigyelései]. Ehhez mérten a jelen esetsorozatban a viszonylag hosszú medián követési idő kapcsán tapasztalt mintegy $22 \%$-os előfordulás kedvezőnek mondható.

Gyakorlati szempontból a letermovir profilaxis alkalmazása nem ütközött számottevő nehézségekbe. Az antifungális triazolok vonatkozásában felmerülő gyógyszer- kölcsönhatások kockázata azok rendszeres szérumszint monitorozásával minimálisra csökkenthető. A legjelentősebb kihívást egyéb vírusinfekciók egyidejű fellépte jelentheti. Mivel a letermovir csak a hCMV-re fejti ki gátló hatását egyéb vírusok vonatkozásában második profilaxis bevezetésére és nukleinsav-alapú monitorozásra van szükség. A HSV és VZV okozta infekciók megelőzése és kezelése aciclovirral megoldható. Problémát jelent azonban a nagy kockázatú transzplantáltakban mind gyakrabban észlelt HHV-6 reaktiváció. A HHV-6 ellenes stratégia optimális kialakítását nehezíti a PCR eredmények bizonytalan interpretálhatósága (pl. kromoszomálisan integrált vírus DNS lehetősége miatt), illetve az ezzel kapcsolatos nemzetközi irányelvek konzervativizmusa. Mivel a HHV-6 reaktiváció kapcsán potenciálisan halálos központi idegrendszeri infekció, pneumonitis, graft-rejekció, elhúzódó T-sejtes immunrekonstitúció is felléphet, egyedi klinikai döntés alapján a HHV-6 DNS pozitív személyekben szükség lehet foscarnet vagy ganciclovir bevezetésére [10]. Ilyenkor a letermovir átmeneti felfüggesztésére is sor kerülhet.

Összefoglalásként megállapíthatjuk, hogy az első, valós életből származó klinikai tapasztalatok megerősítik a letermovir profilaxis hatékonyságát és biztonságosságát az allogén őssejt-transzplantált hCMV infekciójának megelőzése terén. Miután egyes betegek kockázati időszaka különösen a GvHD miatt szükségessé váló tartós immunszuppresszió miatt - meghosszabbodhat, fontos lenne, ha további tudományos eredmények birtokában mód nyílna a vegyület használatára a +100 . poszttranszplantációs napon túl is.

Nyilatkozat: Jelen közlemény eredeti kézirat, más folyóiratban vagy elektronikus felületen korábban nem jelent meg. A levelező szerző kijelenti, hogy a szerzői útmutatót elolvasta.

Érdekeltségek: A szerzőknek nincsenek érdekeltségeik. Anyagi támogatás: A cikk megjelenését az MSD Pharma Hungary Kft. tette lehetővé. Az itt közölt információk a szerző(k) (eredményeit és) véleményét tükrözik, amely eltérhet az MSD Pharma Hungary Kft. álláspontjától. A megemlített termékek használatakor az érvényes alkalmazási előírás az irányadó.

Szerzői munkamegosztás: A kézirat elkészítésében a szerzők azonos arányban vettek részt.

Köszönetnyilvánitás: A szerzők köszönetüket fejezik ki Miskolczi Gottfriednek és Tresó Bálintnak a vírusdiagnosztikai vizsgálatok elvégzéséért és az értékes tanácsokért, együttmüködésért.

\section{Irodalom}

[1] de Melo Silva J, Pinherio-Silva R, Dhiani A, et al. Cytomegalovirus and Epstein-Barr Infections: Prevalence and Impact on $\mathrm{Pa}$ tients with Hematological Diseases. Biomed Res Int. 2020; 1627824. DOI: $10.1155 / 2020 / 1627824$ 
[2] Sinkó J. Current treatment modalities of immunocompromised patients with cytomegalovirus infection. I. Epidemiological and clinical perspectives. [Aktualitások a sérült immunitású betegek cytomegalovírus-infekcióinak ellátásában. I. Epidemiológia és klinikai szempontok.] Orv Hetil. 2019; 160: 83-92. [Hungarian]

[3] Ljungman P, de la Camara R, Robin C, et al. Guidelines for the management of cytomegalovírus infection in patients with haematological malignancies and after stem cell transplantation from the 2017 European Conference on Infections in Leukaemia (ECIL 7). Lancet Infect Dis. 2019; 19: e260-e272.

[4] Sinkó J. Current treatment modalities of immunocompromised patients with cytomegalovirus infection. II. Therapeutic options and management strategies. [Aktualitások a sérült immunitású betegek cytomegalovírus-infekcióinak ellátásában. II. Terápiás lehetőségek és ellátási stratégiák.] Orv Hetil. 2019; 160: 363-369. [Hungarian].

[5] European Medicines Agency. Previmys. Summary of product characteristics. https://www.ema.europa.eu/en/documents/productinformation/prevymis-epar-product-information_en.pdf [accessed October 17, 2021].
[6] Marty F, Ljungman P, Chemaly RF, et al. Letermovir Prophylaxis for Cytomegalovirus in Hematopoietic-Cell Transplantation. Engl J Med. 2017; 377: 2433-2444.

[7] Cassanti I, Colombo AA, Bernasconi P, et al. Positive HCMV DNAemia in stem cell recipients undergoing letermovir prophylaxis is expression of abortive infection. Am J Transplant. 2021; 21: $1622-1628$

[8] Royston L, Royston E, Masouridi-Levrat S, et al. Letermovir Primary Prophylaxis in High-Risk Hematopoietic Cell Transplant Recipients: A Matched Cohort Study. Vaccines (Basel). 2021; 9: 372.

[9] Malagola M, Pollara C, Polverelli N, et al. Advances in CMV Management: A Single Center Real-Life Experience. Front Cell Dev Biol. 2020; 8: 534268.

[10] Hill JA. Human herpesvirus 6 in transplant recipients: An update on diagnostic and treatment strategies. Curr Opin Infect Dis. 2019; 32: 584-590.

A cikk a Creative Commons Attribution 4.0 International License (https://creativecommons.org/licenses/by/4.0/) feltételei szerint publikált Open Access közlemény, melynek szellemében a cikk bármilyen médiumban szabadon felhasználható, megosztható és újraközölhető, feltéve, hogy az eredeti szerző és a közlés helye, illetve a CC License linkje és az esetlegesen végrehajtott módosítások feltüntetésre kerülnek. (SID_1) 